\title{
Growth Inhibitory Effects of Chlorine Dioxide on Bacteria
}

\author{
Kyoung-Ju Song ${ }^{1, *}$ and Suk-Yul Jung ${ }^{2, \dagger ; * *}$ \\ ${ }^{1}$ Purgofarm Co. Ltd, Hwasung-city, Gyeonggi 18627, Korea \\ ${ }^{2}$ Department of Biomedical Laboratory Science, Molecular Diagnosis Research Institute, \\ Namseoul University, Chungnam 31020, Korea
}

\begin{abstract}
Chlorine dioxide $\left(\mathrm{ClO}_{2}\right)$ gas is a neutral chlorine compound. $\mathrm{ClO}_{2}$ gas was proven to effectively decontaminate different environments, such as hospital rooms, ambulances, biosafety level 3 laboratories, and cafeterias. In this study, to evaluate the effects of $\mathrm{ClO}_{2}$ gas, bacteria of clinical importance were applied. Staphylococci, Streptococci and Bacillus strains were applied and Klebsiella, and others e.g., Escherichia coli, Shigella, Salmonella, Serratia were also done for the inhibitory analysis. Bacteria plates were applied with a hygiene stick, namely, "FarmeTok (Medistick/Puristic)" to produce $\mathrm{ClO}_{2}$. $\mathrm{ClO}_{2}$-releasing hygiene stick showed the very strong inhibition of bacterial growth but had different inhibitions to the bacteria above $96.7 \%$ except for MRSA of $90 \%$ inhibition. It is difficult to explain why the MRSA were not inhibited less than others at this point. It can be only suggested that more releasing $\mathrm{ClO}_{2}$ should be essential to kill or inhibit the MRSA. B. subtilis, S. agalactiae, S. pyogenes, E. coli O157:H7, S. typhi (S. enterica serotype typhi) and S. marcesence were inhibited over 99\%. This study will provide fundamental data to research growth inhibition by $\mathrm{ClO}_{2}$ gas with bacteria of clinical importance value.
\end{abstract}

Key Words: Chlorine dioxide, Bacteria, Inhibition, FarmeTok (Medistick/Puristic)

Chlorine dioxide $\left(\mathrm{ClO}_{2}\right)$ gas is a neutral chlorine compound. It is very different from elementary chlorine, both in its chemical structure and in its behavior (Vogt et al., 2010; Song and Jung, 2017).

$\mathrm{ClO}_{2}$ gas is an effective disinfectant agent with strong oxidization ability and a broad biocidal spectrum (GómezLópez et al., 2009; Wang et al., 2016). The antimicrobial efficacy of $\mathrm{ClO}_{2}$ gas has been evaluated in previous studies, and $\mathrm{ClO}_{2}$ gas was proven to effectively decontaminate different environments, such as hospital rooms (Luftman et al., 2006; Lowe et al., 2013), ambulances (Lowe et al., 2013), biosafety level 3 laboratories (Lowe et al., 2012), and cafe- terias (Hsu et al., 2014).

It has been reported that chlorine dioxide, a strong oxidant, can inhibit or destroy microorganisms (Ogata et al., 2008; Morino et al., 2009; Sanekata et al., 2010; Ma et al., 2017; Ofori et al., 2017). Sanekata et al., (2010) reported that chlorine dioxide at concentrations ranging from 1 to 100 ppm produced potent antiviral activity, inactivating $>$ or $=$ $99.9 \%$ of the viruses with a $15 \mathrm{sec}$ treatment for sensitization.

Our group has reported that in the clinics 11 microorganisms were isolated, and $\mathrm{ClO}_{2}$-releasing hygiene stick showed the very strong inhibition of bacterial growth with about 99.9\% after $24 \mathrm{hr}$ incubation (Song and Jung, 2017).

Received: August 7, 2018 / Revised: August 17, 2018 / Accepted: August 23, 2018

* Chief Technology Officer, ${ }^{* *}$ Professor.

${ }^{\dagger}$ Corresponding author: Suk-Yul Jung. Department of Biomedical Laboratory Science, Molecular Diagnosis Research Institute, Namseoul University, 91 Daehak-ro, Seonghwan-eup, Seobuk-gu, Cheonan-city, Choongnam 31020, Korea.

Tel: +82-41-580-2723, Fax: +82-41-580-2932, e-mail: syjung@nsu.ac.kr

(C) The Korean Society for Biomedical Laboratory Sciences. All rights reserved.

(c) This is an Open Access article distributed under the terms of the Creative Commons Attribution Non-Commercial License (http://creativecommons.org/licenses/by-nc/3.0/) which permits unrestricted non-commercial use, distribution, and reproduction in any medium, provided the original work is properly cited. 
$\mathrm{ClO}_{2}$ however was found to increase the permeability of the outer and cytoplasmic membranes leading to the leakage of membrane components such as $260 \mathrm{~nm}$ absorbing materials and inhibiting the activity of the intracellular enzyme $\beta$-Dgalactosidase (Ofori et al., 2017).

In this study, to evaluate the effects of $\mathrm{ClO}_{2}$ gas, bacteria of clinical importance were applied.

Six gram positive bacteria and five gram negative bacteria were applied. Bacteria were mentioned in results with growth inhibition data. Briefly, 2 Staphylococci, 2 Streptococci and 1 Bacillus strains were applied and 2 Klebsiella, and others e.g., Escherichia coli, Shigella, Salmonella, Serratia were also done for the inhibitory analysis. In this study, the bacteria were not divided by characteristics of diseases but simply described with human infections above. Single colonies were subcultured into other tryptic soy agar (TSA, MB cell, Korea) plate at $37^{\circ} \mathrm{C}$, and were double checked by Gram-staining procedures (Lim et al., 1988).

To culture accurate colonies, obtained single colonies were diluted with $0.85 \% \mathrm{NaCl}$ and were adjusted into 0.5 of McFaland turbidity, which could produce about $1.5 \times 10^{3}$ to $1.5 \times 10^{6}$ colony forming units $(\mathrm{CFU}) / \mathrm{mL}$ (Song and Jung, 2017). The adjusted bacteria grown in TSA plates were applied for all subsequent experiments.

Bacteria plates were applied with a hygiene stick, namely, "FarmeTok (Medistick/Puristic) kindly provided by Purgofarm, co, Ltd. (Hwasung, Gyeonggido, Korea)" to produce $\mathrm{ClO}_{2}$ (Song and Jung, 2017). To efficiently observe and culture bacteria, bacterial plates were added into a plastic clear chamber $(250 \mathrm{~W} \times 350 \mathrm{D} \times 200 \mathrm{H})$ at a $37^{\circ} \mathrm{C}$ incubator.

Table 1. CFU of bacteria by the hygiene stick of $\mathrm{ClO}_{2}$ gas. Bacteria were streaked onto the plate and the hygiene stick was located near the plate followed by counting of bacterial colonies

\begin{tabular}{|c|c|c|c|c|c|}
\hline $\begin{array}{l}\text { Gram } \\
\text { staining }\end{array}$ & $\begin{array}{c}\text { Bacteria } \\
\text { (No. at KCTC) }\end{array}$ & Groups & $\begin{array}{l}\text { Initial numbers } \\
(\mathrm{CFU} / \mathrm{mL})\end{array}$ & $\begin{array}{l}\text { Numbers after } 24 \mathrm{hr} \\
(\mathrm{CFU} / \mathrm{mL})\end{array}$ & $\begin{array}{c}{ }^{*} \text { Growth inhibition rate } \\
(\%)\end{array}$ \\
\hline \multirow{10}{*}{+} & \multirow{2}{*}{ S. aureus (1621) } & Control & $1.5 \times 10^{4}$ & - & - \\
\hline & & $\mathrm{ClO}_{2}$ & $1.5 \times 10^{4}$ & $<250$ & 98.3 \\
\hline & \multirow{2}{*}{$\begin{array}{l}\text { Methicillin-resistant } \\
\text { S. aureus (MRSA) }\end{array}$} & Control & $1.5 \times 10^{3}$ & - & - \\
\hline & & $\mathrm{ClO}_{2}$ & $1.5 \times 10^{3}$ & $<150$ & 90.0 \\
\hline & \multirow{2}{*}{ B. subtilis (3613) } & Control & $1.5 \times 10^{6}$ & - & - \\
\hline & & $\mathrm{ClO}_{2}$ & $1.5 \times 10^{6}$ & $<50$ & 99.9 \\
\hline & \multirow{2}{*}{ S. agalactiae } & Control & $1.5 \times 10^{5}$ & - & - \\
\hline & & $\mathrm{ClO}_{2}$ & $1.5 \times 10^{5}$ & $<150$ & 99.0 \\
\hline & \multirow{2}{*}{ S. pyogenes } & Control & $1.5 \times 10^{4}$ & - & - \\
\hline & & $\mathrm{ClO}_{2}$ & $1.5 \times 10^{4}$ & $<50$ & 99.7 \\
\hline \multirow{12}{*}{-} & \multirow{2}{*}{ E. coli $\mathrm{O} 157: \mathrm{H} 7$} & Control & $1.5 \times 10^{4}$ & - & - \\
\hline & & $\mathrm{ClO}_{2}$ & $1.5 \times 10^{4}$ & $<50$ & 99.7 \\
\hline & \multirow{2}{*}{ K. oxytoca (1686) } & Control & $1.5 \times 10^{4}$ & - & - \\
\hline & & $\mathrm{ClO}_{2}$ & $1.5 \times 10^{4}$ & $<300$ & 98.0 \\
\hline & \multirow{2}{*}{ K. pпиетопіае } & Control & $1.5 \times 10^{3}$ & - & - \\
\hline & & $\mathrm{ClO}_{2}$ & $1.5 \times 10^{3}$ & $<50$ & 96.7 \\
\hline & \multirow{2}{*}{$\begin{array}{l}\text { S. typhi } \\
\text { (S. enterica serotype typhi) }\end{array}$} & Control & $1.5 \times 10^{4}$ & - & - \\
\hline & & $\mathrm{ClO}_{2}$ & $1.5 \times 10^{4}$ & $<100$ & 99.3 \\
\hline & \multirow{2}{*}{ S. marcesence } & Control & $1.5 \times 10^{6}$ & - & - \\
\hline & & $\mathrm{ClO}_{2}$ & $1.5 \times 10^{6}$ & $<100$ & 99.9 \\
\hline & \multirow{2}{*}{ S. sonnei } & Control & $1.5 \times 10^{4}$ & - & - \\
\hline & & $\mathrm{ClO}_{2}$ & $1.5 \times 10^{4}$ & $<300$ & 98.0 \\
\hline
\end{tabular}

*100 - (Numbers after $24 \mathrm{hr} /$ Initial numbers) $\times 100$ 
Bacterial growth was periodically observed until $24 \mathrm{hr}$ and was compared with $\mathrm{ClO}_{2}$ gas-untreated groups as a control.

All bacterial strains were below: $S$. aureus, Methicillinresistant S. aureus (MRSA), B. subtilis, S. agalactiae, $S$. pyogenes, E. coli $\mathrm{O} 157: \mathrm{H7}$, K. oxytoca, K. pnuemoniae, $S$. typhi (S. enterica serotype typhi), S. marcesence, S. sonnei. To analyze whether chlorine dioxide can inhibit the bacteria, hygiene stick, namely, "FarmeTok (Medistick/Puristic)" which produced the chlorine dioxide gas was co-incubated with the bacteria. To avoid the release of the gas out, the hygiene stick was put into a plastic chamber and was incubated at $37^{\circ} \mathrm{C}$.
When the $\mathrm{ClO}_{2}$-releasing hygiene stick is ready for activation, it is changed into yellow and release $\mathrm{ClO}_{2}$ (Song and Jung, 2017).

Simply, the lid of bacterial plates was open to be released to air and $\mathrm{ClO}_{2}$. Bacteria were streaked onto the plate and the hygiene stick was located near the plate followed by counting of bacterial colonies (Table 1). Bacterial numbers were different dud to the use of general growth media of TSA. $\mathrm{ClO}_{2}-$ releasing hygiene stick showed the very strong inhibition of bacterial growth but had different inhibitions to the bacteria above $96.7 \%$ except for MRSA of $90 \%$ inhibition. It

\section{(A)}

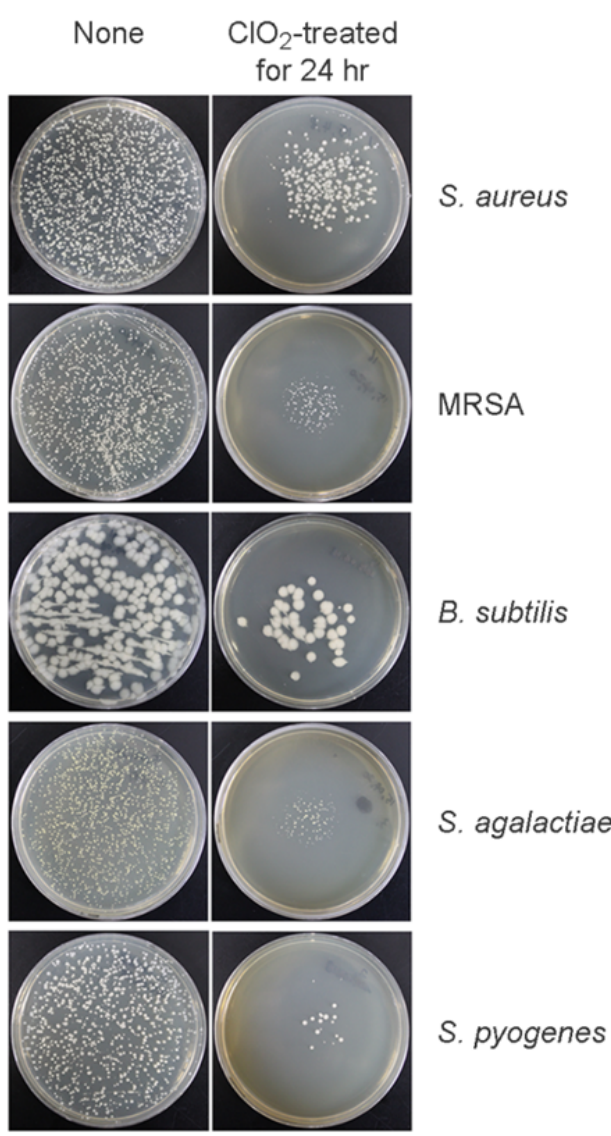

B

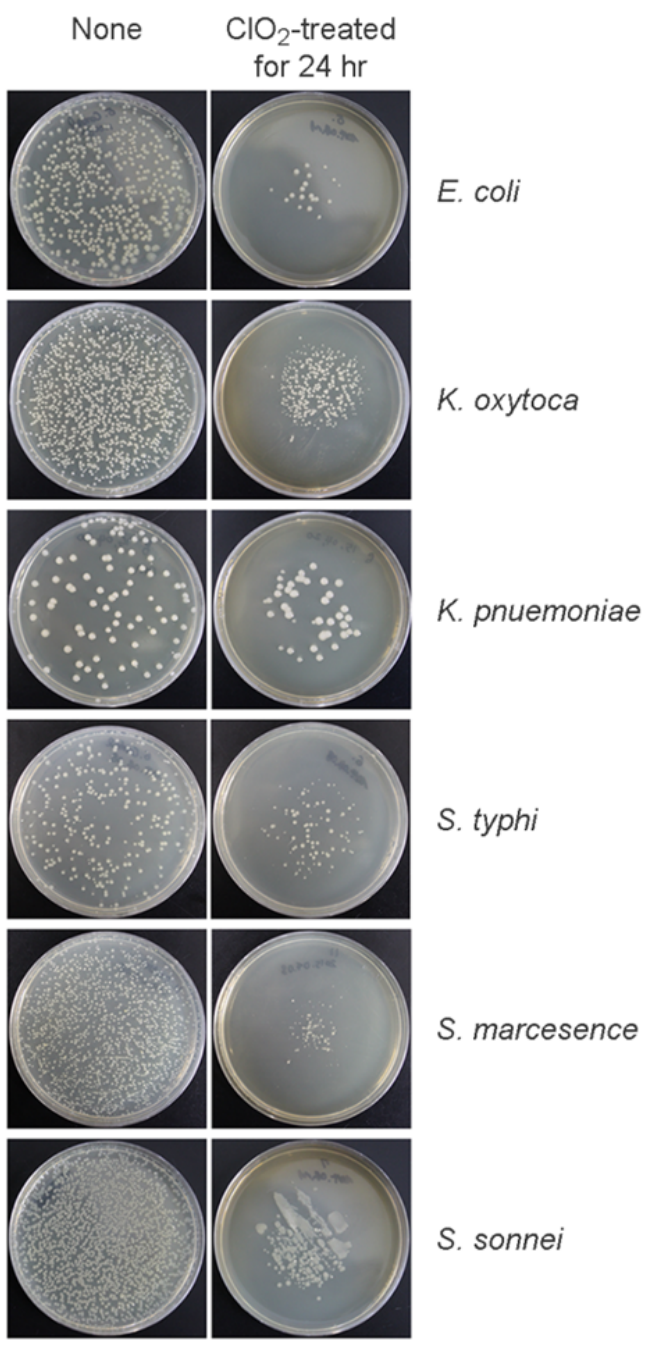

Fig. 1. Bacterial plates by the co-incubation of the hygiene stick of $\mathrm{ClO}_{2}$ gas. Bacteria plates were applied with a hygiene stick to produce $\mathrm{ClO}_{2}$. The bacterial plates were added into a plastic clear chamber at a $37^{\circ} \mathrm{C}$ incubator. Bacterial growth was periodically observed until $24 \mathrm{hr}$ and was compared with $\mathrm{ClO}_{2}$ gas-untreated groups as a control. 
is difficult to explain why the MRSA were not inhibited less than others at this point. It can be only suggested that more releasing $\mathrm{ClO}_{2}$ should be essential to kill or inhibit the MRSA. B. subtilis, S. agalactiae, S. pyogenes, E. coli O157:H7, S. typhi (S. enterica serotype typhi) and $S$. marcesence were inhibited over $99 \%$. It can also suggest that the inhibition may not be affected by the Gram positivity and Gram negativity.

Fig. 1. represented bacterial plates from the counting of CFU. All bacteria could be easily counted post $24 \mathrm{hr}$ coincubation with $\mathrm{ClO}_{2}$, but $S$. sonnei plate showed dispersed patterns due to moisturized surface of the plate. Very interestingly, the areas of growth inhibited plates were peripheral but not the central, implied that diffusion of $\mathrm{ClO}_{2}$ gas affect the margin and periphery at first and then go to the central region.

$\mathrm{ClO}_{2}$ gas is required to sanitize a lot of areas and an equipment to release the $\mathrm{ClO}_{2}$ gas may be necessary in hospitals. The hygiene stick, namely, "FarmeTok (Medistick/Puristic)" kindly provided by Purgofarm would be useful to release $\mathrm{ClO}_{2}$ gas and were sufficient to inhibit bacterial growth for $24 \mathrm{hr}$ release. In our previous study, 11 microorganisms including Micrococcus luteus, Granulicatella adiacens, Staphylococcus caprae, Sphingomonas paucimobilis, Kocuria kristinae, etc which were isolated from the clinic were completely inhibited by the hygiene stick of $\mathrm{ClO}_{2}$ gas (Song and Jung, 2017). Incomplete growth inhibition may be resulted from different pathogenicity of those bacteria and this applied bacteria.

All 11 bacterial strains in this study possess different pathogenicity and require different growth media. TSA medium was only used to check the bacterial growth, even if the bacteria grew faster or slower. Interestingly, MRSA was not completely inhibited by the hygiene stick of $\mathrm{ClO}_{2}$ gas, in view of the $90 \%$ inhibition. The difference of its pathogenicity might be definitely described, but MRSA was antibioticsresistant bacterium of interests. Other 10 bacteria are killed by broad antibiotics, but MRSA is characterized by resistance. Even though only one antibiotics-resistant bacterium was applied here, it implied that antibiotics-resistant bacteria require more dose of $\mathrm{ClO}_{2}$ gas to be killed or growthinhibited.

Some bacteria can be applied in specific condition and environments. No detectable levels of E. coli (limit of detection $5 \log$ ) were determined in the water within 1 min after E. coli was added to the $\mathrm{ClO}_{2}$ containing wash water (Banach et al., 2018). And Five $\mathrm{mg} / \mathrm{L}$ of $\mathrm{ClO}_{2}, E$. coli was reduced $>5$ orders of magnitude after $3 \mathrm{~min}$ (COD 1,130 $\mathrm{mg} \mathrm{O}_{2} / \mathrm{L}$ ) (Haute et al., 2017). Concentrations of $\mathrm{ClO}_{2}$ up to $385 \mathrm{ppm}$ were safely maintained in a hospital room with enhanced environmental controls (Lowe et al., 2013). In this study, the released $\mathrm{ClO}_{2}$ gas concentration was $13 \mathrm{ppmv} / \mathrm{hr}$ (data not shown), so we suggest that this 'ready-to-use- $\mathrm{ClO}_{2}$ stick' maybe useful tool for inhibition of nosocomial infection.

This study will provide fundamental data to research growth inhibition by $\mathrm{ClO}_{2}$ gas with bacteria of clinical importance value.

\section{ACKNOWLEDGMENTS}

Funding for this paper was provided by Namseoul University.

\section{CONFLICT OF INTEREST}

The authors have no conflicts of interest to disclose.

\section{REFERENCES}

Banach JL, van Overbeek LS, Nierop Groot MN, van der Zouwen PS, van der Fels-Klerx HJ. Efficacy of chlorine dioxide on Escherichia coli inactivation during pilot-scale fresh-cut lettuce processing. Int J Food Microbiol. 2018. In press.

Gómez-López VM, Rajkovic A, Ragaert P, Smigic N, Devlieghere F. Chlorine dioxide for minimally processed produce preservation: a review. Trends Food Sci Technol. 2009. 20: 17-26.

Hsu CS, Lu MC, Huang DJ. Effect of gaseous chlorine dioxide on student cafeteria bioaerosols. Clean. 2014. 42: 12-19.

Lowe JJ, Gibbs SG, Iwen PC, Smith PW. A case study on decontamination of a biosafety level-3 laboratory and associated ductwork within an operational building using gaseous chlorine dioxide. J Occup Environ Hyg. 2012. 9: 196-205.

Lowe JJ, Hewlett AL, Iwen PC, Smith PW, Gibbs SG. Evaluation of ambulance decontamination using gaseous chlorine dioxide. Prehosp Emerg Care. 2013. 17: 401-408.

Lowe JJ, Gibbs SG, Iwen PC, Smith PW, Hewlett AL. Impact of chlorine dioxide gas sterilization on nosocomial organism viability in a hospital room. Int J Environ Res Public Health. 2013. 
10: 2596-2605.

Lim KB, Boey LP, Khatijah M. Gram's-stained microscopy in the etiological diagnosis of Malassezia (Pityrosporon) folliculitis. Arch Dermatol. 1988. 124: 492.

Luftman HS, Regits MA, Lorcheim P, Czarneski MA, Boyle T, Aceto H, allap B, Munro D, Faylor K. Chlorine dioxide gas decontamination of large animal hospital intensive and neonatal care units. Appl Biosaf. 2006. 11: 144-154.

Luftman HS, Regits MA, Lorcheim P, Lorcheim K, Paznek D. Validation study for the use of chlorine dioxide gas as a decontaminant for biological safety cabinets. Appl Biosaf. 2008. 13: 199-212.

Ma JW, Huang BS, Hsu CW, Peng CW, Cheng ML, Kao JY, Way TD, Yin HC, Wang SS. Efficacy and safety evaluation of a chlorine dioxide solution. Int J Environ Res Public Health. 2017. 14: E329.

Morino H, Fukuda T, Miura T, Lee C, Shibata T, Sanekata T. Inactivation of feline calicivirus, a norovirus surrogate, by chlorine dioxide gas. Biocontrol Sci. 2009. 14: 147-153.

Ofori I, Maddila S, Lin J, Jonnalagadda SB. Chlorine dioxide oxidation of Escherichia coli in water - A study of the disinfection kinetics and mechanism. J Environ Sci Health A Tox Hazard Subst Environ Eng. 2017. 52: 598-606.

Ogata N, Shibata T. Protective effect of low-concentration chlorine dioxide gas against influenza A virus infection. J Gen Virol. 2008. 89: 60-67.

Sanekata T, Fukuda T, Miura T, Morino H, Lee C, Maeda K, Araki K, Otake T, Kawahata T, Shibata T. Evaluation of the anti- viral activity of chlorine dioxide and sodium hypochlorite against feline calicivirus, human influenza virus, measles virus, canine distemper virus, human herpesvirus, human adenovirus, canine adenovirus and canine parvovirus. Biocontrol Sci. 2010. 15: 45-49.

Song KJ, Jung SY. Biocidal effects of chlorine dioxide on isolated and identified pathogens from nosocomial environmentbiochemical and technical convergence. J Digit Converg. 2017. 15: 339-344.

Van Haute S, Tryland I, Escudero C, Vanneste M, Sampers I. Chlorine dioxide as water disinfectant during fresh-cut iceberg lettuce washing: Disinfectant demand, disinfection efficiency, and chlorite formation. LWT-Food Sci Technol. 2017. 75: 301 -304 .

Vogt H, Balej J, Bennett JE, Wintzer P, Sheikh SA, Gallone P, Vasudevan S, Pelin K. Chlorine oxides and chlorine oxygen acids, Ullmann's Encyclopedia of Industrial Chemistry, WileyVCH. 2010.

Wang T, Wu J, Qi J, Hao L, Yi Y, Zhang Z. Kinetics of inactivation of Bacillus subtilis subsp. niger spores and Staphylococcus albus on paper by chlorine dioxide gas in an enclosed space. Appl Environ Microbiol. 2016. 82: 3061-3069.

https://doi.org/10.15616/BSL.2018.24.3.270

Cite this article as: Song KJ, Jung SY. Growth Inhibitory Effects of Chlorine Dioxide on Bacteria. Biomedical Science Letters. 2018. 24: 270-274. 